\title{
HOW PARENTS EDUCATION IMPROVE STUDENT ACHIEVEMENT?
}

\author{
Otang Kurniaman ${ }^{1}$, Annisa Indarni ${ }^{2}$, Eddy Noviana ${ }^{3}$ \\ ${ }^{1}$ Universitas Riau \\ ${ }^{2}$ Universitas Riau \\ ${ }^{3}$ Universitas Riau \\ ${ }^{1}$ email-otang.kurniaman@lecturer.unri.ac.id, ${ }^{2}$ email-annisaindarni22@gmail.com, \\ ${ }^{3}$ email-eddy.noviana@ lecturer.unri.ac.id
}

\begin{abstract}
The Education in elementary school is a very important factor. Because the elementary school level is the foundation for the development of children's thinking and learning abilities influences and influences to the next level. The purpose of this research is to determine the academic achievement of students who are influenced by the parent's education level. This research used a quantitative approach with a correlation test. The research conducted at Elementary school of 105 Tampan Pekanbaru to all of grade V students, with 150 total students. The Researcher used the Krejcie and Morgan tables sampling with 108 students. Based on the results of the correlation test shows that the magnitude of the father's education correlation coefficient on student academic achievement is 0.012 while the correlation of maternal education to student academic achievement is 0.081 . Both are below the value of the $\mathrm{r}$ product moment correlation coefficient table for a sample of 108 with a significance level of $5 \%$ that is equal to 0.187 . Thus the hypothesis $\mathrm{H} 0$ is accepted, it means that there is no meaningful relationship between parental education and student achievement.
\end{abstract}

Keywords: Student Academic Achievement, Parent Education

\begin{abstract}
Abstrak
Pendidikan di sekolah dasar adalah faktor yang sangat penting. Karena level sekolah dasar adalah fondasi untuk perkembangan kemampuan berpikir dan belajar anak yang mempengaruhi dan mempengaruhi ke level selanjutnya. Tujuan dari penelitian ini adalah untuk mengetahui prestasi akademik siswa yang dipengaruhi oleh tingkat pendidikan orang tua. Penelitian ini menggunakan pendekatan kuantitatif dengan uji korelasi. Penelitian dilakukan di sekolah dasar 105 Tampan Pekanbaru untuk semua siswa kelas V, dengan total 150 siswa. Peneliti menggunakan sampel tabel Krejcie dan Morgan dengan 108 siswa. Berdasarkan hasil uji korelasi menunjukkan bahwa besarnya koefisien korelasi pendidikan ayah pada prestasi akademik siswa adalah 0,012 sedangkan korelasi pendidikan ibu dengan prestasi akademik siswa adalah 0,081. Keduanya di bawah nilai tabel koefisien korelasi momen produk $\mathrm{r}$ untuk sampel 108 dengan tingkat signifikansi 5\% yaitu sama dengan 0,187. Dengan demikian hipotesis H0 diterima, itu berarti bahwa tidak ada hubungan yang bermakna antara pendidikan orang tua dan prestasi belajar siswa.
\end{abstract}

Kata Kunci: Prestasi Akademik Mahasiswa, Pendidikan Orangtua

\section{INTRODUCTION}

Education has a different meaning from schooling. The most essential emphasis of the two words is the education means liberating people from backwardness, ignorance, civilization, freeing humanity from the bonds that bind humanity. While schooling is a tool in education that directs and brings human beings to get that freedom, which leads to motivation so as to be able to develop maximum intellectuals of students (Frielinkac \& Embregts, 2013). The learning process is fully directed at developing these three domains (cognitive, affective, psychomotor) 
in full, meaning that the development of one domain cannot be separated from the other domains (Kurniaman \& Noviana, 2013). According to the parent education who influence the intelligence of students by providing guidance at home and teachers play in education in schools that are able to provide positive contributions to student intelligence (Sakhiyya, Agustien, \& Pratama, 2018). Therefore, the low quality of education can be seen from the teacher's teaching style in the class whether it is able to provide learning that is able to increase student change in a positive direction and be able to become a facilitator in learning (Bustami, Syafruddin, \& Afriani, 2018).

School is the place where the children can learn regularly and children can achieve their desired goals. Children are social beings who will be the next generation for the future, children also need other people to care for love and love (Hanani, 2013). For this reason family, friends and social environment determine the maturity of children in the future (Friedman \& Spassiani, 2018). School is a strategic vehicle that allows every student, with a diverse socio-cultural background, to interact with each other, to mutually absorb cultural values, and can increase knowledge. Schools become a means for each student to learn and play roles and perform functions according to the position and status in the school structure (Suharsimi, 2018). Parents are role models for their children, so parents must guide and direct them to things that are good and educating. The purpose of basic education is to lay the basis of intelligence, knowledge, personality, noble character, and skills to live independently and follow further education. Broadly speaking, it can be concluded as follows, that the implementation of basic education is emphasized in laying the foundation of knowledge and skills where at this level students or children only capture and manage the facts (Dewantoro, 2017).

Education is also influenced by various things including the level of education of the parents of the students themselves. As it is understood that the level of income of the people (especially parents) will influence their motivation in providing education to their children, as well as the children themselves as students. Based on this, it is natural that the economic abilities of parents play a role in improving the quality of education, especially for their children. That is, education is not just released, because there are other things where parents also determine success in meeting the needs of their children in education. In this case, parents provide facilities and facilities for their children to learn (Dewi \& Kurniaman, 2019). Parents are the parent of learning for a child because the family is the first and foremost place as the child's educational environment. Parents have the obligation to care for, care for, and guide a 
child before going to school, children also need positive encouragement from parents to do something. That is part of the way to give mental strength to children (Kartika, 2013).

The Elementary School 105 is not the best school in Tampan District. In terms of the number of teachers and students the ratio is 1: 28 means that one teacher serves 28 students. This number falls into the category of both the size of the primary school. These students from SDN 105 Tampan amounted to 873 students consisting of grade 1 to grade 6 . With an average distribution per class 35 - 38 people with variations of class A to D. The spread of 873 students was divided into various socio-economic backgrounds of the guardians of his students. With this variation of course the socio-economic abilities of the community will be different in providing learning tools for their children, this difference will affect the academic achievement of their students. Because learning is a process of absorption of knowledge that often creates a saturation for children, especially parents who do not pay too much attention to how their children learn. So that it has an impact on children's achievement results. In this case, every parent wants the best for their children, usually anything parents will do to help their child's learning achievements. But it was realized that the low achievement of students in Indonesia was one of the factors due to the low awareness and participation of parents. The low awareness of parents of students is also very related to the economic capacity of the community. This study tries to explain how the academic achievements of elementary school students are influenced by parental education?

Discussing this further, it needs to be understood that the concept of learning is a complex internal process, which is involved in internal processes which include affective elements, in the affective dimension related to attitudes, values, interests, appreciation, and adjustment of social feelings. This means that learning is a change in behavior due to the interaction between individuals in their environment so as to gain experience (Ngalimun, 2012; Zufriady \& Kurniaman, 2019). Based on the study of several definitions, it can be concluded that learning is a process of activities carried out by someone who produces a new change in behavior as a result of interaction with the environment. This is because education is a human right. Human rights are inherent rights to every human being based on their nature that comes from God and cannot be disturbed and sued by anyone. Thus human rights are fundamental rights as human beings (Noviana and Munjiatun, 2015).

Talking about the indicator output of educational is student academic achievement. This statement was made clear by Misyani and Antosa (2018) which states that achievement is the result of a person's accomplishments through learning that results in real and new behaviors. 
While learning achievement is interpreted as a measure of knowledge obtained from formal education and is shown through test scores (Tu'us, 2009). According to Sukardjo and Komaruddin (2012) said: "achievement is the result achieved by someone when working on a task or activity". Whereas according to Slameto (2013) "learning is a business process carried out by someone to obtain a change in new behavior as a whole, as a result of his own experience in interaction with his environment". Meanwhile, it is believed that parents who have a higher level of education and knowledge must have greater advantages in terms of income, time, energy and contact networks, which makes them further monitor their children's education. While parents who have minimal knowledge only give motivation to their children because of limited knowledge possessed by their parents (Myklebust, 2007). In addition, the family is responsible for providing funds for children's educational needs because those related to education require no small amount of funds.

\section{METHOD}

This research was conducted at SDN 105 Tampan of Pekanbaru City, the time the research was held on December 14, 2018 - January 16, 2019. The research instrument used questionnaires and observations. The population in this study were all students of class $\mathrm{V}$ which numbered 150 students. Based on the Krejcie and Morgan tables with a population of 150 students, the samples were taken as many as 108 students, after the number of samples was known, the samples were taken using a simple random technique. For the category of assessment of the level of education of parents and student achievement measured by the rating scale (rating scale). This rating scale is more flexible not limited to just attitude measurement, but also to measure socio-economic status, education, employment, knowledge, abilities and others (Sugiyono, 2010). Thus the category of parental education is scaled: Bachelor (3), Senior High School (2) and Junior High School (1). Parents is consist of husband and wife, namely the sundent's father and mother, there is a variation of education between them. To calculate this category the author will add the variations as follows: 
Table 1. Parent's Education Level Category

\begin{tabular}{|c|c|c|c|c|c|}
\hline \multirow[t]{2}{*}{ No } & \multicolumn{2}{|c|}{ Parent's education level Category } & \multirow[t]{2}{*}{ Score } & \multirow[t]{2}{*}{ Score } & \multirow[t]{2}{*}{ Total score } \\
\hline & Father & Mother & & & \\
\hline 1 & Bachelor & Bachelor & 3 & 3 & 6 \\
\hline 2 & Bachelor & $\begin{array}{l}\text { Senior High } \\
\text { school }\end{array}$ & 3 & 2 & 5 \\
\hline 3 & Bachelor & Junior High school & 3 & 1 & 4 \\
\hline 4 & Senior High school & Bachelor & 2 & 3 & 5 \\
\hline 5 & Senior High school & $\begin{array}{l}\text { Senior High } \\
\text { school }\end{array}$ & 2 & 2 & 4 \\
\hline 6 & Senior High school & Junior High school & 2 & 1 & 3 \\
\hline 7 & Junior High school & Bachelor & 1 & 3 & 4 \\
\hline 8 & Junior High school & $\begin{array}{l}\text { Senior High } \\
\text { school }\end{array}$ & 1 & 2 & 3 \\
\hline 9 & Junior High school & Junior High school & 1 & 1 & 2 \\
\hline
\end{tabular}

Student academic achievement is measured from the total score of all odd semester 2018/2019 academic lessons obtained from each class. Then the way to determine the distinguishing power of student academic achievement, according to Arikunto (2018), is distinguished between small groups (less than 100) and large groups (100 people and above). The large group is divided into two poles, namely the top $27 \%$ as the upper group (Ja) and the lowest $27 \%$ as the bottom group $(\mathrm{Jb})$. Because the number of students used as respondents amounted to 108 , then $27 \%$ of the 108 students who were made into the top group were numbers 1 - 29, the medium group was numbers 30-79 and the lower group numbers $80-108$. So, the authors immediately set: 3 is high ranking, 2 is ranked medium and 1 is ranked low. Data collected using questionnaires and documentation Analysis of data using descriptive quantitative by calculating the frequency and data mode.

Variable X (Independent) is the level of education of parents of students. The level of education of the parents of these students is quite diverse, but none of them have elementary school education. This shows that the education level of parents lately is better than in the past. However, there is a variation in the level of education of the parents of these students, does it have an influence on the academic achievements of students at Elementary School 105 Pekanbaru Tampan? For this reason, this study will be explained further.

While the Y variable (dependent) is student academic achievement. This student's academic achievement consists of 3 categories, namely: high ranking, moderate ranking and low ranking. Parental education is assumed if the higher education of parents, means the higher 
the level of care for their children's education, and vice versa. Knowledge possessed by parents is predicted to have an influence on his understanding of education in his family which in turn will also affect his child's academic performance. To see the relationship between parents' educational status and student achievement, product moment correlation techniques were used. The reasons for using it are as follows:

1. Variables that will be correlated in the form of symptoms that are continuous.

2. The sample studied has a homogeneous or near homogeneous nature

3. The regression is linear regression.

The requirements that must be fulfilled if we use this formula are:

1. Sampling from the population must be random (random).

2. Variation in the score of the two variables to be sought for correlation must be the same.

Product Moment Correlation formula as follows:

$$
r x y=\frac{n \sum x y-\left(\sum x\right)\left(\sum y\right)}{\sqrt{N \sum x^{2}-\left(\sum x\right)^{2}\left(N \sum y^{2}-\left(\sum y\right)^{2}\right.}}
$$

Information :

${ }^{\mathrm{r}} \mathrm{x} y=$ correlation coefficient between $\mathrm{X}$ and $\mathrm{Y}$ variables

$\sum x y=$ the number of multiplications between the variabels $\mathrm{X}$ and $\mathrm{Y}$

$\sum x^{2}=$ sum of squared $X$

$\sum \mathrm{y}^{2}=$ sum of squared $\mathrm{Y}$

$\left(\sum \mathrm{x}\right)^{2}=$ the number of values of $\mathrm{X}$ is then squared

$\left(\sum \mathrm{y}\right)^{2}=$ the number of values of $\mathrm{Y}$ is then squared

Based on the Calculate product moment correlation by using SPPS software version 24, with a significance level of $5 \%$ from the value of the product moment.

\section{RESULTS AND DISCUSSION}

\section{Results}

The results of this study from the number of respondents 108 students found parent data with a general description seen at the age level of parents of students and fifth grade students of SDN 105 Tampan as follows: 
Table 2. Age Of Parents Specified According To Student Gender

\begin{tabular}{|c|c|c|c|c|c|c|}
\hline \multirow{3}{*}{$\begin{array}{c}\text { Gender of The Students } \\
\text { Grade V } \\
\text { SDN 105 Tampan } \\
\end{array}$} & \multicolumn{4}{|c|}{ Parent's Age (Year) } & \multirow[t]{3}{*}{ Total } & \multirow[t]{3}{*}{$\%$} \\
\hline & \multicolumn{2}{|c|}{$35-40$} & \multicolumn{2}{|c|}{$40-45$} & & \\
\hline & Father & Mother & Father & Mother & & \\
\hline Male & 15 & 25 & 23 & 10 & 73 & 67.59 \\
\hline Female & 17 & 6 & 8 & 4 & 35 & 32.41 \\
\hline Sub total & 32 & 31 & 31 & 14 & - & - \\
\hline Total & \multicolumn{2}{|c|}{63} & \multicolumn{2}{|c|}{45} & 108 & - \\
\hline Percentage & \multicolumn{2}{|c|}{58.33} & \multicolumn{2}{|c|}{41.67} & - & $100 \%$ \\
\hline
\end{tabular}

The fifth grade students of SDN 105 Tampan Pekanbaru were targeted for study, the average age of their parents both their father and mother aged $35-40$ were 63 people $(58.33 \%)$, while the parents of students aged $40-45$ years were 45 people or $41.67 \%$. The range of age of parents of students between 35-40 years of age with having children who attend school in the fifth grade in elementary schools and aged between 10-11 years is reasonable. Thus their average age at marriage is at least 20 years old. Furthermore, to see the distribution of student age and gender collected from this study, are as follows:

Table 3. Distribution of Student Academic Achievement and Parental Education

\begin{tabular}{|c|c|c|c|c|c|c|}
\hline \multicolumn{2}{|c|}{$\begin{array}{c}\text { Student's Parent } \\
\text { Education }\end{array}$} & \multicolumn{3}{|c|}{ Student Acadenic Achievement } & \multirow[t]{3}{*}{ Total } & \multirow[t]{3}{*}{$\%$} \\
\hline & & \multirow{2}{*}{$\begin{array}{c}\text { High } \\
\text { Achievement } \\
(1-29) \\
\end{array}$} & \multirow{2}{*}{$\begin{array}{c}\text { Medium } \\
\text { Achievement } \\
(30-79)\end{array}$} & \multirow{2}{*}{$\begin{array}{c}\text { Low } \\
\text { Achievement } \\
(\mathbf{8 0}-\mathbf{1 0 8}) \\
\end{array}$} & & \\
\hline Father & Mother & & & & & \\
\hline Bachelor & Bachelor & 1 & 5 & 1 & 7 & 6.50 \\
\hline Bachelor & $\begin{array}{l}\text { Senior } \\
\text { High } \\
\text { School }\end{array}$ & 11 & 17 & 13 & 41 & 37.96 \\
\hline Bachelor & $\begin{array}{l}\text { Junior } \\
\text { High } \\
\text { School }\end{array}$ & 3 & 5 & 6 & 14 & 12.96 \\
\hline $\begin{array}{l}\text { Senior High } \\
\text { School }\end{array}$ & Bachelor & 3 & 6 & 0 & 9 & 8.33 \\
\hline $\begin{array}{l}\text { Senior High } \\
\text { School }\end{array}$ & $\begin{array}{l}\text { Senior } \\
\text { High } \\
\text { School }\end{array}$ & 7 & 10 & 7 & 24 & 22.22 \\
\hline $\begin{array}{l}\text { Senior High } \\
\text { School }\end{array}$ & $\begin{array}{l}\text { Junior } \\
\text { High } \\
\text { School }\end{array}$ & 4 & 7 & 2 & 13 & 12,03 \\
\hline Total & & 29 & 50 & 29 & 108 & - \\
\hline Percentage & & $26.85 \%$ & $46.30 \%$ & $26.85 \%$ & - & 100 \\
\hline
\end{tabular}


The results of the research that the authors have done at SDN 105 Tampan Pekanbaru found academic achievement of class $\mathrm{V}$ students consisting of 4 class $\mathrm{V}$ study groups a, b, c and $\mathrm{d}$ with a total of 108 respondents the average academic achievement of their students was classified as a moderate achievement category (46, 30\%). High achievement and low achievement with the same number $(26.85 \%)$ spread across all class V study groups at SDN 105 Tampan Pekanbaru. The educational composition of the majority of students' parents is a Bachelor-educated father and a high school-educated mother $37.96 \%$, followed by education of fathers and mothers alike with high school education $22.22 \%$. Thus father's education is still relatively high compared to mother's education. Academic achievements of good students who are categorized as high, medium and low academic achievement are evenly spread among educated parents of undergraduate and high school mothers, even for parents who are equally undergraduate educated with many of their children's academic achievements in the moderate academic achievement category. Furthermore, based on the results of the correlation test conducted, find the following results:

Table 4. Correlation Test Results of Parents' Education Level Against Student Academic Achievement

\begin{tabular}{llrr}
\hline & \multicolumn{1}{c}{$\begin{array}{c}\text { Parent's } \\
\text { Education }\end{array}$} & \multicolumn{1}{c}{$\begin{array}{c}\text { Student } \\
\text { Achievement }\end{array}$} \\
\hline Parent's Education & $\begin{array}{l}\text { Pearson } \\
\text { Correlation }\end{array}$ & 1 & 0.012 \\
\cline { 2 - 4 } & Sig. (2-tailed) & 108 & 0.904 \\
\cline { 2 - 4 } & $\mathrm{N}$ & 0.012 & 108 \\
\hline Student Achievement & Pearson & & 1 \\
& Correlation & 0.904 & 108 \\
\cline { 2 - 4 } & Sig. (2-tailed) & 108 & $\mathrm{~N}$ \\
\cline { 2 - 4 } & $\mathrm{N}$ & & \\
\hline
\end{tabular}

The results of the correlation test indicate that the magnitude of the correlation coefficient of education of parents (father and mother) of students towards student academic achievement is 0.012 . This value turns out to be smaller than the value of the $r$ product moment correlation coefficient table for a sample of 108 with a significance level of $5 \%$ that is equal to 0.187. Thus the hypothesis $\mathrm{HO}$ which states "There is no effect of parental education on the academic achievement of fifth grade students of SDN 105 Tampan Pekanbaru " accepted. This 
means that there is no meaningful relationship between parental education and the achievement of class V students of SDN 105 Tampan Pekanbaru.

The results of these statistical tests show that there is no relationship between the level of education of parents on the achievement of class students. Thus the level of education of parents does not have a significant effect on student academic achievement. Students from parents with high or low education are equally likely to have high or low academic achievements. The assumption that the level of education of parents characterized by the level of education contributes to student achievement. This is because the parents' education is considered as one of the external factors that provide stimulation to student achievement. But the results of the correlation test for each of the parents' education level variables are all below the rejection rate of significance level.

\section{Discussion}

The research findings explain that the learning process is held to teach students to achieve their intended goals, so that student achievement will be achieved in accordance with educational goals. The results obtained by students through learning can be said as learning achievement. This is in accordance with the opinion of Tu '(2009) that learning achievement is the result of learning achieved by students when following and working on learning tasks at school. It is undeniable that the level of education of children is very closely related to the income / income of the parents they produce from work, parents are obliged to finance all of their children's education needs. In this case the income of parents is one of the factors that influence the level of education of children. Income or income is money received by a person or company in the form of salary, rent, wages, interest, and profits in a certain period of time as a form of reward from business activities carried out (Fitrianingsih, Genjik \& Rosyid, 2017).

The role of parents' education level is very important, because parents will understand the importance of education for their children. This is because parents are the main and first educators for their children, because from them the children first receive education. Thus the main form of education is in family life. it is this family that the child gets care from parents towards the direction of his development. From childhood, children are cared for and raised by and in the family. Everything in the family, both in the form of objects and people and the rules and customs that apply in the family are very influential and determine the style of development of children. How to educate the prevailing family. Such is the way the child reacts to his environment. Father and mother in the context of ideal family life, is the figure closest to the 
child. Father and mother are the main role takers as parents to care for their children. Especially the closeness of the child to the mother, because the mother is supportive, giving birth and breastfeeding so psychologically has a deeper bond (Mediabki, 2017).

The suitability of teacher teaching styles with student learning styles becomes an important aspect in creating and implementing learning that will culminate in student academic achievement. The suitability of students' learning styles with the right teaching style will result in successful interactions between teachers and students and their learning outcomes will improve (Kurniaman \& Huda, 2018). When the teacher is able to create learning that is consistent with the tendency of students' learning styles, students will be easy to process information so that eventually they can achieve high learning achievement. it can be seen that subjects experience learning barriers, namely drowsiness when learning is not in accordance with the learning style they have (Kurniaman \& Zufriady, 2019). As a formal environment that provides education for children, schools cannot be excluded from family education and how to apply it. Parental support for home learning activities combined with parental involvement in children's schools is very important for the children's education process. Growing research shows that building effective relationships between parents, families, and schools to support children's learning can lead to increased learning outcomes. Parents are the first teachers and continuously educate children. Research also shows that teacher quality, including standards and training, is an important factor that influences the facilitation of parent-educator relations (Lia, 2016).

\section{CONCLUSION}

The results of this research about the Academic Achievement Analysis of Elementary School Students Affected by the Education of Parents in SDN 105 Tampan Pekanbaru 105. The correlation test results show that the magnitude of the correlation coefficient of parental education on student academic achievement of 0.012 is below the value of the correlation coefficient $r$ product moment table for a sample of 108 with a significance level of $5 \%$ that is equal to 0.187 . Thus the hypothesis H0 which states "There is no difference in achievement of class V students of SDN 105 Tampan Pekanbaru with the education status of their parents", accepted. This means that there is no meaningful relationship between parental education and the achievement of class V students of SDN 105 Tampan Pekanbaru. 
Journal of Elementary Education

Volume 5, Number 1, February 2021
P-ISSN: 2580-9326

E-ISSN: 2580-7714

\section{REFERENCES}

Bustami, Y., Syafruddin, D., \& Afriani, R. (2018). The Implementation Of Contextual Learning To Enhance Biology Students' Critical Thinking Skills. Jurnal Pendidikan IPA Indonesia, 7(4), 451-457. DOI: 10.15294/jpii.v7i4.11721.

Dewantoro, H. (2017). Pengertian Pendidikan Dasar. [Online] Retrieved on 22-May-2019, at URL: https://silabus.org/pendidikan-dasar/.

Dewi, Y.E., \& Kurniaman, O. (2019). Analisis Keterampilan Dasar Menjelaskan oleh Guru Dalam Mengajarkan Membaca Permulaan Siswa Tunagrahita di SDLB Kasih Ibu Pekanbaru. Primary: Jurnal Pendidikan Guru Sekolah Dasar, 8 (1), 37-46. DOI: http://dx.doi.org/10.33578/jpfkip.v8i1.6361.

Frielink, N., \& Embregts, P. (2013) Modification of motivational interviewing for use with people with mild intellectual disability and challenging behavior. Journal of Intellectual and Developmental Disability, 38(4), 279-291, DOI: 10.3109/13668250.2013.809707.

Friedman, C., \& Spassiani, N. A. (2018). Community-Based Dietician Services for People With Intellectual and Developmental Disabilities. Journal of Policy and Practice in Intellectual Disabilities, 15(4), pp 343-349. doi: 10.1111/jppi.12253.

Fitrianingsih, Genjik. B. S., \& Rosyid, R. (2017). Pengaruh Pendapatan Orang Tua Terhadap Tingkat Pendidikan Anak Desa Sungai Asam Kabupaten Kubu Raya. Jurnal Pendidikan Dan Pembelajaran Khatulistiwa.

Hanani, S. (2013). Sosiologi Pendidikan Keindonesiaan. Yogyakarta: Ar-ruzz Media.

Kurniaman, O., \& Noviana, E. (2013). Penerapan Kurikulum 2013 dalam Meningkatkan Keterampilan, Sikap, dan Pengetahuan. Primary: Jurnal Pendidikan Guru Sekolah Dasar, 6(2), 389- 396.

Kurniaman, O., \& Zufriady. (2019). The Effectiveness of Teaching Materials for Graphic Organizers in Reading in Elementary School Students. Journal of Educational Sciences, 3(1), 48-62.

Kurniaman, O., \& Huda, M. H. (2018). Penerapan Strategi Bercerita Untuk Meningkatkan Keterampilan Menyimak Siswa Kelas III SD Muhamadiyah 6 Pekanbaru. Primary: Jurnal Pendidikan Guru Sekolah Dasar, 7(2), 249-255.

Kartika. (2013). Pengaruh Peranan orang Tua Terhadap Pendidikan Anak. [Online] Retrieved on 22-May-2019, at URL: https://www.kompasiana.com/bahasa.kita/552888af6ea83439058b45a8/pengaruhperanan-orangtua-terhadap-pendidikan-anak.

Lia. (2016). 10 Peran Orang Tua dalam Mendidik Anak di Era Globalisasi. [Online] Retrieved on 22-May-2019, at URL: https://cintalia.com/kehidupan/orang-tua/peran-orang-tuadalam-mendidik-anak. 
Misyani \& Antosa, Z. (2018). Penerapan Model Pembelajaran Inkuiri Untuk Meningkatkan Hasil Belajar IPA Siswa Kelas IV SD Negeri 6 Kadur, Jurnal Online Mahasiswa Universitas Riau, 5(1), 1- 12.

Myklebust, J.O. (2007). Diverging paths in upper secondary education: competence attainment among students with special educational needs. International Journal of Inclusive Education, 11(2), 215-231, DOI: 10.1080/13603110500375432.

Mediabki, N.A. (2017). Pengaruh Pendidikan Orang Tua Terhadap Perkembangan Anak. [Online] Retrieved on 22-May-2019, at URL: https://nurulauliamediabki.wordpress.com/2017/06/01/pengaruh-jenjang-pendidikanorangtua-terhadap-perkembangan-anak/.

Ngalimun, (2012). Strategi dan Model Pembelajaran, Aswaja Pressindo, Yogyakarta.

Noviana, E.\& Munjiatun, (2015). Hand Out : Konsep Dasar Pendidikan Kewarganegaraan di Sekolah Dasar, Program Studi PGSD Jurusan Pendidikan, FKIP Universitas Riau, Pekanbaru.

Sakhiyya, Z., Agustien, H. I. R., \& Pratama, H. (2018). The reconceptualisation of knowledge base in the pre-service teacher education curriculum: Towards ELF pedagogy. Indonesian Journal of Applied Linguistics, 8(1), 49-56. doi: 10.17509/ijal.v811.11464.

Sugiyono. (2010). Metode Penelitian Pendidikan Pendekatan Kuantitatif, Kualitatif dan R\&D. Bandung: Alfabeta.

Suharsimi, A. (2018). Dasar-dasar Evaluasi Pendidikan. Jakarta: Bumi Aksara.

Sukardjo, M.,\&Komarudin,U, (2012). Landasan Pendidikan: Konsep dan Aplikasinya. Jakarta : Rajawali Pers.

Tueeu, T. (2009). Peran Disiplin pada Perilaku dan Prestasi Siswa. Jakarta: Grasindo.

Zufriady, Z., \& Kurniaman, O. (2019). The Effectiveness of Learning Basic Concepts of Art for Primary Teacher Education Students Using Nomor Acak Learning Model. Mimbar Sekolah Dasar, 6(1), 3242.doi:http://dx.doi.org/10.17509/mimbarsd.v6i1.15241. 